\author{
St udia Philosophic a \\ Wr a t i s l a vi e n s i a \\ vol. XIV, fasc. 1 (2019) \\ DOI: $10.19195 / 1895-8001.14 .1 .11$
}

\author{
POVILAS ALEKSANDRAVIČIUS \\ ORCID: 0000-0002-6569-3544 \\ Mykolas Romeris University
}

\title{
Strategies of Perception of Europe and Their Reception in Lithuania*
}

\begin{abstract}
This article analyses strategies of perception of Europe that fit into a triple structure. The traditional division into philosophical, cultural, and political Europe is intersected with more fundamental European perceptions determined by different ways of thinking. In this article, these ways are referred to as the closed, the open and the hollow ones. Thus, three different conceptions of Europe arise: the closed Europe characterized by essentialism, ethnocentrism, and monologic consciousness; the open Europe based on the standpoint that protection of one's own identity and maturity depend on a dialogic relationship with representatives of other identities; and the hollow Europe that makes absolute the imperative of moral self-criticism, as well as identity's deconstruction and its relativism. The discussion of all three strategies of perception of Europe is followed by the analysis of how they were received in Lithuania. The conclusion highlights the necessity to further research the relationship between all three conceptions of European identity.
\end{abstract}

Keywords: European identity, closed Europe, open Europe, hollow Europe

\section{Introduction}

The perception of Europe as a unified entity is subject to various strategies. In this paper, I offer an interpretation of these strategies and try to synthesize the historiography of European research that has in recent decades grown into colossal

\footnotetext{
${ }^{*}$ This research was funded by a grant (No. S-MOD-17-19) from the Research Council of Lithuania
} 
dimensions. Another part of the paper will focus on the reception of these strategies in one of the peripheral states of Europe, Lithuania.

My interpretation is grounded in the intersection of two viewpoints that stem from an alternative methodological perspective. The first viewpoint posits that the thinking about Europe can be structural. In this option, three approaches to the concept of Europe can be distinguished: (1) the philosophical, (2) the cultural, and (3) the political. This structural grouping of the perception of Europe is universally accepted. However, all analyses of the philosophical, cultural, and political Europe can be subjected to an alternative type of perception of Europeanness altogether. This approach to thinking about Europe can also be divided into three groups. Two of them are universally acknowledged and frequently analysed; they form a natural opposition that has become a historiographical paradigm of identity. The opposition runs, on the one hand, between "closedness," more elegantly called essentialism or ethnocentricity, and "openness," on the other. H. Bergson (1932) and K.R. Popper (1945) were first to formulate this paradigm of closedness/openness. There is a multitude of interpretations of Europe effected from such a perspective; some of them take original formulations, as in Th. Maissen's scheme of exclusive/ inclusive and particularism/universalism (Maissen 2016: 160-162). It has to be noted, however, that the concepts of openness and closedness are insufficient if one intends to assess adequately the strategies of the perception of Europe that prevail in today's historiography. Therefore, it is necessary to introduce a third concept that implies something that the classic conceptions of open and closed European identity do not contain - specifically, the principle of negation of Europe as a unit of identity that follows the logic of postmodern deconstructionism. This third concept captures a standpoint which may be called the absolute axiological relativism, and which strongly influenced the discourse about Europe in recent decades. Since it determines the perception of the European identity as an ontologically-empty identity, I suggest to refer to this third concept using the term "hollowness." The meaning of "an ontologically-empty identity" will be explained below. As will be seen, this concept characterises the third strategy of the perception of Europe as distinct from the two based on the concepts of openness and closedness.

\section{Three Europes from the Structural Perspective}

\subsection{The Philosophical Europe}

The philosophical concept of Europe expresses an idea that Europeanness finds its articulation in universally rational (philosophical) categories. To understand Europe philosophically means to stress the specificity of the European thinking and the European way of life, as well as its role in the global development of humanity. The hugely influential R. Brague's work Europe, the Romanian Way (1992) is an example of a philosophical understanding of Europe. Building on a number of historical sources that enable him to conduct the comparative analysis of Western civilisations, the author suggests an original interpretation of the European identity, according it with a feature previously associated with the ancient 
Roman civilisation: the ability to turn something foreign into something one's own. The European identity itself was formed after Romans adapted Greek and Jewish sources; this Roman attitude has historically defined Europe's relationship with the world. I shall return to Brague when identifying the strategy of identity's openness that functions in his work. Another work known for its philosophical interpretation of Europe is E. Husserl's The Crisis of European Sciences and Transcendental Phenomenology of 1936 (1970). Husserl defines Europe as a site of emergence of a universal and rational thinking par excellence, that is, as the motherland of a universal truth. Hence its ultimate aim, telos, stands in relation to the entire humanity. Through the development of the Greek rational thinking, Europe expresses in itself a spiritual aim of all nations and even individuals: "The spiritual telos of European humanity, in which the particular telos of particular nations and of individual man is contained, lies in the infinite, is an infinite idea toward which, in concealment, the whole spiritual becoming aims" (Husserl 1970: 275). J. Patočka continued Husserl's vision in his own manner. In his Plato and Europe (2002), Patočka analyses the possibilities inscribed in Plato's philosophy and interprets their realisation as a spiritual programme of Europe's historical life, to define Europeanness as "care for the soul." Both Husserl and Patočka offer a comprehensive interpretation of the historical development of Europe. They reveal the spiritual Greek element as the essence of authentic Europeanness and the driving force of its historical expression: for Husserl, it is the intuition of the idea of eternal infinity, for Patočka - it is the care for the soul. Both of them carefully detach this element from those tendencies of European history that are not subject to it and that take the shape of instrumentalization of mind in the horizon of all kinds of violence. Thus, historically, there are two Europes: the Europe that is loyal to its philosophical vocation and the Europe that betrays this vocation. From this perspective, the philosophical Europe is understood as a criteriological basis for interpreting the historical Europe.

\subsection{The Cultural Europe}

The perception of Europe as an entity of cultural identity stems from attempts to distinguish the main lines of the historical evolution of Europe and by interpreting their mutual relationship. It is common to regard these lines as the Greco-Roman heritage, the Jewish-Christian religion, and the modern tradition of rationality associated with the age of Enlightenment. The hermeneutic viewpoint of appropriation/fracture clearly dominates the historiography that presents the cultural Europe; according to this viewpoint, the Greco-Roman heritage is appropriated and transformed by the Christian thinking, from which Europe dissociates in modern times through the process of secularization. Though this scheme is generally accepted and though there is a more or less universally understanding that none of the three aforementioned traditions have lost their importance altogether, the relationship between Christianity and modernity sometimes provokes ardent debates. A widely circulated (often appearing in history textbooks) 19th-century view that the changes that took place during the age of Enlightenment were pro- 
voked by resistance not only to historical Christianity but also to the very essence of Christian thinking has been radically revised by the argument that the process of secularization itself is rooted in Christianity. However, this argument also comes in an entire spectrum of interpretations. The recently resurgent C. Schmitt, for instance, develops M. Weber's conception of secularization to argue that concepts of modernity are actually concepts of Christian theology expressed through non-religious modalities (1970). Meanwhile, M. Gauchet establishes a claim that Christianity is a "religion of exodus from religion" (1985).

Whatever the interpretation of Christianity as a basis of European modernity is considered, the cultural Europe, in any of its historical development stages, is uniformly perceived as a locus of expression of a pretension to humanist universality. The Greco-Roman culture expresses a conscious attempt to represent the cosmos not merely in the natural, but also in the social sense (cosmopolitanism), best exemplified by the Roman empire unifying various nations into one empire and juridically acknowledging their rights. Christianity grafted into the European thinking the category of human dignity (imago Dei) that arises out of a natural human state the divine act of creation - and hence the equality of all people in the presence of the theological absolute. The rationality of modern times is to be regarded as universal and, as such, as pushing every representative of any nation towards liberation from regionalism and towards openness to the universal value of humanity. Thus, the cultural identity of Europe opens up to the possibility of interpretation of the philosophical Europe. Later, I will demonstrate how paradigmatically different strategies of perception of Europe penetrate this cultural and philosophical pretension and how controversially it can be assessed from the ethical perspective.

A detailed typology of the cultural identity of Europe depends on the specific definition of the concept of culture employed in the analysis. Representing the multiple possible definitions is not my aim. Still, I will mention one more segment of the historical process that is decisive for the contemporary perception of Europe and that forms the context of any of its cultural conceptions. In the 19th and 20th centuries, the idea of a sovereign nation-state became a political reality. The European pretension to humanist universality was interpreted through the prism of national sovereignty, and this caused a specific tension in European thinking, one between universal human values and values of a particular nation. Thus, from the 19th century onwards, the perception of Europe has been determined by various interpretations of its relationship with sovereign (European) nations. Moreover, this relationship presumably forms the main element of the multi-fold strategies of approaching Europe: quite clearly, it determines not merely the cultural, but also the political perception of Europe.

\subsection{The Political Europe}

The idea of the political Europe is a conception of a specific political system that unifies the European nations. It is determined by a two-fold objective - that of peace and protection. On the one hand, the political Europe has to realize an internal peace project because a common cultural dimension-no matter how 
nice the idea of a universal European philosophical and cultural humanism may seem - has been and is insufficient when seeking to stop bloody conflicts between its nations. On the other hand, a politically-unified Europe seeks to protect itself from various external factors that pose danger to its identity and values. The first concrete project of political Europe was formulated when the Turks took over Constantinople in 1453: the Bohemian king, George of Podebrady, suggested in 1464 that all Christian kingdoms should create a European confederation governed by a General Council and a President and even unified by a common currency that would ensure funding for a European army necessary to protect Europe from the danger posed by the Turks. Starting with the 17th and 18th centuries, the idea of a union of European states has become an object of permanent discussions. The most famous examples of such discussions include the project of Elizabeth I, the Queen of England, and Henry IV, the King of France, according to which all European states had to form a common "Christian Republic" administered by a 66-member Senate elected for three years; a plan of Abbé de Saint-Pierre presented in a treatise $A$ Lasting Peace through the Federation of Europe that had a strong impact on the 18th century intellectuals, especially Rousseau and Kant. Notably, Kant's work Perpetual Peace can also be regarded as a presentation of the principles substantiating the idea of the political Europe. Paradoxically, although European history in the 19th century can be interpreted as a gradual slide to the brutal conflicts of the first half of the 20th century, one also notices that, perhaps of its tragic trajectory, the period also gave the idea of the political Europe a new momentum, as is evident in V. Hugo's speeches on "the United States of Europe." It is precisely the insupportable nature of conflicts that determined that the political Europe would become a reality after World War II - a reality that has effectively protected intra-European peace since the war and guards the European identity in the whirlpools of contemporary globalization.

Revisiting these well-known episodes of European history may help us become aware of the fundamental problem of the political Europe - a problem that determines the nature of the European perception and whose solution determines Europe's future. Each example deals with the problem of the relationship between political nationalism (national sovereignty) and political supranationalism. On the one hand, the problem arises because of the relentless inclination to treat the concept of a supranational political identity using categories that define national identity. On the other, it is made more acute because of the perception that the concept of the supranational political identity has not become part of the European consciousness but is merely in its initial stage of crystallization. The intensity of discussions on this issue is well illustrated by the in-depth and mutually intersecting visions of political Europe described in J. Habermas (2006) and P. Manent (2006). Some of the most precise and fundamental analyses of the problem are provided by J.-M. Ferry (2005, 2010), a professor at the University of Nantes, whose thinking, which subtly articulates the European concepts of telos, nomos, and ethos, could become a principle of a renewed perception of the political Europe. Nevertheless, the problematic nature of the political, cultural, and philosophical Europe becomes most vibrantly visible only when the perception strategies are 
identified on another level, where they vary between the closed, the open and the hollow thinking paradigms.

\section{Three Europes from the Ways of Thinking Perspective}

Before I present the three different ways of thinking that suggest three different Europes, it is important to note that these ways of thinking refer to tendencies rather than stable states. One may seldom (most probably never) encounter perfect closedness, openness, or hollowness. Similarly, the real ways of thinking of individual persons ought to be regarded as intermediary stages. Nevertheless, the tendencies one can establish are as clear as they are instructive, and to them I now turn.

\subsection{The Closed Europe}

The closed way of thinking is developing in two directions. In historiography, it is common to refer to them as "essentialism" and "ethnocentrism," though the latter may imply not only national but also religious or cultural (in its widest sense) centralizing around one's identity's ego. These two closed ways of perceiving one's identity can, of course, be intertwined.

In the case of essentialism, identity is perceived as having absolute value and a finite and effectively unchanging substance. The cultural, folk, national, religious, or linguistic expressions of this substance are seen as possessing a canonical status; accordingly, every attempt at changing them is viewed as a threat to the very identity. Thus essentialism forms a consciousness of a monologic type, which does not see any worth in a dialogue with those subscribing to different identities, or, in an extreme case, sees this dialogue as dangerous and, therefore, to be avoided (Aleksandravičius 2016). Consequently, representatives of a monologic consciousness view the relationship with a different identity as a boundary that cannot be overstepped or, in extreme cases, as a perpetual threat to be destroyed.

S. Huntington's theory of the clash of civilisations is based precisely on this paradigm of closed thinking or closed identity (Huntington 1996). A more fundamental analysis of political essentialism was done by K.R. Popper (1945). In the field of philosophical anthropology, H. Bergson provides one of the most comprehensive explanations of this tendency by discussing static religion and closed society (Bergson 1932). Notably, all three see Europe as a certain exception in the panorama of world civilisations. Though each stresses the European inclination towards essentialism, in their eyes, European closedness is historically and systemically in tension with an incomparably stronger tendency (relative to other civilisations) towards openness. This dynamic strategy of perceiving Europe as a closedness corrected by a relentless flight to openness - is among the main and typical ways of interpreting Europe.

However, the purely essentialist interpretation of Europe is just as prevalent, particularly among the general public. Still, as my aim is to identify the types of 
perception of Europe that appear in philosophical reflection rather than to provide their sociological nor psychological analysis, I will be referring only to philosophical texts. A typically essentialist conception of Europe is found in C. Schmitt's work The Concept of the Political (1996), which was written on the eve of the Nazis' arrival to power in Germany. The concept of politics here is subordinated to the conception of a centralized State with a powerful apparatus of government while the State itself is understood as an engine of a nation's homogeneity and gathering according to clear-cut essentialist criteria as well as protection from an enemy. The appearance of an enemy is seen as the essential moment of a nation's consolidation into a State; at this moment, the singularity of a nation's identity comes to the fore. From this perspective, Europe is merely a pluriversum of States that regulates its internal relationships according to the categories of friend and enemy. Of course, if such a strategy of perception is adopted, Europe is dissolved into separate nations and its expression of identity can only unfold within the boundaries of each of its nations.

As this identity of Europe is perceived according to a model of national identity, it is interpreted differently on the structural level. As a political concept, Europe is weak and, since all political power belongs to an absolutely sovereign nation-state, the idea of politically united Europe can only be an unnecessary fiction-unless it is unified by one of its states, that is. It is here that the substantiation of nationalist ideology emerges and Europe becomes a land of wars between nations. Political Europe here is an impossible Europe. At the same time, the idea of the cultural and philosophical Europe comes to the fore when positing other civilisations as Europe's competitors. Historically, the essentialist understanding of the cultural and/or philosophical Europe substantiated the doctrine of colonialism. Though colonialist politics was implemented by individual sovereign nation-states, they were unified by the same myth of European superiority. Therefore, the phenomenon of European colonialism is better understood from the perspective of the other dimension of closedness - ethnocentricity.

Before moving on to the analysis of Europe as closed ethnocentric identity, it is necessary to note that the understanding of a closed political Europe is impossible only when the sovereign nation-state is seen as the benchmark of political organization. It becomes possible when the sovereign nation-state loses this status and a group of countries starts to be seen as the political absolute. After World War II, Schmitt created his geopolitical theory of "big spaces" (Grossraum) according to which Europe (on the basis of Germany (!)) should form such a space, unified by its shared Christian culture and prepared to protect itself from other big spacesother and potentially hostile civilisations. From this perspective, the political Europe is the cultural Europe subjected to the closed way of thinking. P. Sloterdijk's (1994) idea of reviving the imperial principle of European political organization can be interpreted as one example of such thought.

Ethnocentricity highlights different qualities than essentialism: its focus is the superiority of one's identity relative to others rather than the permanence of one's identity. More often than not, ethnocentricity even welcomes identity evolution as a fundamental value but, by always interpreting change as a product of internal 
resourcefulness, it highlights the quality of own identity and devaluates other identities. Generally, the devaluation of a different identity is the main feature of ethnocentricity: qualitatively lower other identities are valuable only insofar as they reflect the characteristics of my identity. Husserl's philosophical conception of Europe is often interpreted from the ethnocentric perspective, following his statement in The Crisis of European Sciences, "There is something unique here that is recognized in us by all other human groups, too, something that, quite apart from all considerations of utility, becomes a motive for them to Europeanize themselves even in their unbroken will to spiritual self-preservation; whereas we, if we understand ourselves properly, would never Indianize ourselves, for example" (1970: 275). Having grasped the "infinite idea" through the rationality of its thinking dating back to ancient Greece, Europe has nothing to learn from other civilisations. On the contrary, as it forms the criteriology for assessing the quality of thinking of other nations, other civilisations can learn from Europe. Thus E. Tassin can state that, "In Husserl's vision, just like in Patočka's, Europe indeed does not show any humble intention to enter into acquaintance with the non-European world: Europe itself $i s$ the world because Europe supposedly houses the spirit of the entire humanity in its specific spirit" (Tassin 2013: 255). Nevertheless, depending on how the concept of "infinity" is understood, Husserl's conception can also be interpreted in line with another strategy of perceiving Europe - one grounded in the paradigm of open identity.

\subsection{The Open Europe}

The open way of self-perception, or the conception of open identity, resists the ideas of identity's fixity and superiority, and suggests that maintaining one's own identity necessitates the identity of Other. Interpreting the dynamics of human existence from this perspective reveals a complex structure of identity that was characterized by Paul Ricoeur as "oneself as another"- the phrase with which he entitled of one of his major works. "Oneself as Another suggests from the outset that the selfhood of oneself implies otherness to such an intimate degree that one cannot be thought of without other, that instead one passes into the other" (Ricoeur 1992a: 3). It is noteworthy that such a categorical statement of the necessity of Other does not imply the demand to deny or devalue in any other way one's own identity - something observed in the case of the hollow identity. On the contrary, Other is understood as an integral part of one's own identity, as a driver of maturing and a source of vitality. Such a position in a person's private and social life forms a dialogic consciousness that is expressed as an active seeking to know other's identity by at least partly integrating it into one's own identity in such a way that neither of them suffers but, on the contrary, each becomes richer and more mature (Aleksandravičius 2016). The open identity functions according to the dynamics of a narrative that constantly edits and re-creates itself. Human, folk, religious, and national narratives change according to a constantly renewing integration of a previously unknown world, or a different horizon, that presupposes certain universal ethical requirements (Ricoeur 1992a). Continuing Ricoeur's con- 
ception of a narrative identity, J.-M. Ferry discerns two additional formative moments of an authentic identity - the argumentative and the reconstructive. During "argumentation," an individual gets to know, assesses, probes, and makes decisions about a different identity. Afterwards, the "reconstruction" of one's own identity - of one's own narrative - takes place; at this stage, the narrative identity has already integrated the knowledge and the acknowledgement of the other and has assumed new responsibility both for oneself and for the other.

The strategy of perception of Europe that prevails in historiography interprets Europe as the motherland of the concept of open identity and as its major bastion in philosophical, cultural, and political spheres. Thus, the European identity itself is interpreted as a historical incarnation of the open identity that defines the criteria for European authenticity. As J.-F. Mattéi notes, the analyses of Ricoeur or Ferry "are merely an innovative phraseological formulation of what philosophical and religious European tradition clearly defined since Plato and St. Paul until Montaigne, Rousseau and Hegel. A self-identifying look acquires self-perception only through meeting with other's self-identifying look. A cross-section of two looks reveals the identity of each one of them that is recognisable in each other's look. Whatever my culture, I cannot understand myself otherwise than in the other's look" (Mattéi 2007: 19). This basic definition of the open European identity does not deny its historical evolution, which has leapt over certain thresholds, such as the symbiosis of Greek and Christian thinking or the re-thinking of the concept of Europeanness in the face of the Turkish threat as well as after the discovery of the New World. Ferry sees the transition to the contemporary perception of an open Europe in Hegel's reflection on civilisations and especially in Wilhelm von Humboldt's conception of linguistic relationships between nations in which the law of "spiritual development of humanity" is formulated (Ferry 2013: 13-21). Hegel establishes the image of European eccentricity (here it is worth remembering Brague's conception) by proposing that the European Spirit is evident in that its life always transcends its own limits. Meanwhile, Humboldt regarded language as an expression of "openness of the world" through which nations, those specific Volksgeist, realise mutual understanding by integrating a common idea of humanity, which simultaneously contains a diversity of identities. To Ricoeur, Humboldt's conception substantiates "the new ethos of Europe," which unfolds through translation, intersecting narratives, and gestures of forgiving (Ricoeur 1992b). Ricoeur also lays out the conception of the open Europe in his famous thesis of "dialogue of memories," by integrating it into his conception of narrative identity. Echoing Ricoeur, E. Morin talks about the "commonality of destinies" of European nations, which is based on the same dynamics of the maturing of individual peculiarities through mutual change (Morin 1987).

Multitudinous research confirms the functioning of such open thinking during the crystallisation of the cultural Europe. For instance, H. Mikkeli, a professor of Helsinki University, authoritatively reveals how, throughout the European history, ancient Greek "reason," Roman "justice," and Christian "clemency" formed a certain symbiosis that determined the specific nature of European culture and constituted a ground for constant attempts at unifying Europe politically (1998). Mattéi 
shows how multiple phenomena of European culture-from the Greek myth to the institutionalisation of modern science in universities - is subject to the same logic of the look that transcends boundaries. This logic underscores numerous forms of mutually open cultural expression that often grow out of each other; for example, such purely European musical genres as symphony or opera stem from the specific nature of Greek science as subtly represented by the 3rd-century mathematician and philosopher Proclus, among others (Mattéi 2007). Indeed, there are too many examples of the perception of the open cultural Europe to list them here. What is important is that all of them are unified by the same idea of discordia concors brilliantly discussed by J. Burckhardt, who shows that European nations, seeking to protect their specificities, have always nolens volens opened up to each other. To Burckhardt, this behaviour is the only possible explanation for the specifically European phenomenon - that, as various ideas or works of culture, art, science spread in the European space, each nation adapted them as their own irrespective of their spatial origin. As evidenced by the strong cultural ties between the English and the Spanish in the 16th-18th centuries, this cultural openness prevailed even during intra-European military conflicts.

The open understanding of the political Europe is best revealed in the contemporary concept of cosmopolitanism that also forms a basis for solving the problem of the relationship between the national and the supra-national European identities. The concept is rooted in the late thinking of Kant when he transformed his philosophical project by supplying it with a cosmopolitan dimension: to think in sensu cosmopolitico is nothing short of fulfilling the ultimate aim of the mind (Cheneval 2005). In Perpetual Peace, Kant lays out his conception of the cosmopolitan unity of Europe by subtly combining ius civitatis, ius gentium, and ius cosmopoliticum - the three levels of public law unifying both individuals and nations. Following the postulates formulated by Kant, Ferry establishes a theory of procedural cosmopolitanism and a model of co-sovereignty, which can substantiate the possibility of the European Union as a plurinational political identity (Ferry 2010). A parallel theory of cosmopolitanism, which is also regarded as an expression of Europeanness and an ideological basis of the European Union, is found in works of U. Beck. In his thought, the cosmopolitan principles of the "European society of societies" and of the association of individuals are understood exactly in line with the definition of open identity as presented above: "Those who integrate the perspective of others into their own lives learn more about themselves as well as others" (Beck 2007: 29). Just like with Ferry's plurinational identity, Beck's conception of the open political Europe combines the principle of nationality with the supra-national perspective. "Cosmopolitan Europe is not only the antithesis of, but also presupposes, national Europe. It cannot transcend national Europe but must cosmopolitanize it from within. In this sense, I speak of a nationally rooted cosmopolitanism" (Beck 2007: 32). The openness of the cosmopolitan Europe is evident in that its supra-nationalism aims not at uniformity of nations but at fostering the diversity of their identities through juridically-based interaction.

This finally refutes the suspicions of ethnocentricity that Europe faces. Even if Brague joins the eccentricity of the European identity with the principle of 
a universal humanist morality, that is, even if he regards Europe as an example for other civilisations to follow, no aim of hierarchical subordination is possible. Even if the European identity has a calling to become universal and, in this sense, to "Europeanize" others, this universality is intended only for its way of thinking - the openness itself-but not for its cultural content. Colonialism which condemns different identities to death, even if carried out by Europeans, has to be seen not as an expansion of Europeanness but rather as its self-destruction. Thus understood, Husserl's conception of Europe too can in no way be regarded as ethnocentric. The idea of infinity, which determines the essence of Europeanness, makes the conditions for identity's possibilities and not the historical shape of identity's substance; as such, Europeanness cannot enter into a competitive relationship with substantive identities of other civilisations. As a graft of certain ethics arising out of the relationship with Infinity, the impact Europeanness has on other identities is indeed tremendous, but it is not an imposition of a particular cultural content. In other words, Europeanness, understood in its essence, wakes in other civilisations the most fundamental ethical possibilities but it does not seek to colonise them culturally or politically. It is in this sense that we should understand Husserl's proposed Europeanness as the humanity's telos, but it is already the meaning of the open, not the closed, European identity.

\subsection{The Hollow Europe}

I refer to the third strategy of the conception of Europe, which arises out of some postulates of postmodern philosophy and which historiographically was established after World War II, as the hollow Europe. I use the term "hollow," as this strategy presupposes a concept of an ontologically-empty identity. This concept is based on the philosophical theory of deconstruction, which states that the concept of identity does not have any support in the existent intelligible reality, independently of human being, but is rather a pure construct of human subjectivity. Ontological hollowness thus implies the non-existence of preliminary ontological determination and the double emancipation of human thinking: in constructing identity, human creativity and ethical criteria become independent of norms of ontologically determined inherent law. The ontological hollowness of identity ensures perpetuality of the possibility to construct and deconstruct content of identity. If the closed identity stresses its substantiality and denies the necessity of change that arises out of relationship with Other, and if the open identity not merely maintains its substance but also opens up to the influence of other identities as a source of one's maturing, then the hollow identity makes the dimension of identity dynamics absolute and in general denies any substantiality of identity. J. Dewitte describes the resultant situation as a "crisis of contours" and sees its typical expression in Derridean posture "neither...nor," in which there is no possibility for any definition of a concept, or, to be more exact, for the stability of a concept's definition (Dewitte 2010: 131-134). On the one hand, such an outlook substantiates ethical axiological relativism; on the other, it demands for treating any substantive identity and, thus, any specific identity that has formed 
historically, with suspicion: it calls to observe whether the identity in question has not become an instrument of power and asserts the necessity to deny it without necessarily offering a replacement. As it extends beyond the scope of this paper, I leave the question of how ethical relativism can be combined with the ethical necessity to deconstruct identity aside.

The substantiation of this third conception of identity appears in the classical texts of postmodernist philosophy, which develops both the thesis of "the end of metaphysics" and the statement of "the end of grand narratives." While the most prominent demonstration of such thinking is found in J.-F. Lyotard's work The Postmodern Condition, R. Rorty's deconstruction of Western metaphysics, whereby he replaces the concept of sociality with aesthetic solidarity ("ironism") and with the conception of individual as a poet "of one's existence," the sole subject of culture, a carrier of multi-culturalism in himself (1989). However, arguably the most fundamental substantiation of identity's deconstruction, both as a theory and a method, was provided by J. Derrida. In his book L'Autre Cap (1991), Derrida also lays out his outlook on Europe's identity, which I consider the most radical example of the third strategy of Europe's perception. Derrida's main idea is that by having to deny both its "Eurocentricity" and "anti-Eurocentricity," its universality and locality, its culture and the denial of culture, Europe cannot have any identity, or, to be more exact, Europe's only possible identity arises out of its identity's non-existence. "The only possible invention is impossible invention" (1991: 43).

From this perspective, it is only natural that the definition of Europe loses sense and even acquires a "phantasmagorical shape," as M. Crépon states following Derrida's example of the "deconstruction of Europe,": "We can no longer agree with the concepts of identity, culture and even spirit (with cultural and/or spiritual identity), that were more or less clearly presupposed by the idea of Europe. [...] European identity is the impossible identity" (2006: 191, 193). However, the hollow European perception is most sharply expressed through the harsh criticism of any substantial European identity - criticism that transforms into a moral imperative to deny it altogether. The theoretical questioning of identity as an instrument of power intertwines here with a moralising and absolutism-prone interpretation of particular facts of European history. Europe's crimes against its own people as well as Europe's guilt against the entire world are assessed as if they would coincide with the very definition of Europe. The well-known saying by S. Sontag, "The truth is that Mozart, Pascal, Boolean algebra, Shakespeare, parliamentary government, baroque churches, Newton, the emancipation of women, Kant, Marx, Balanchine ballets, et al., don't redeem what this particular civilisation has wrought upon the world. The white race is the cancer of human history" perfectly illustrates such a position (1967: 57). Obviously, the proponents of such a viewpoint imply what we have called here the "closed Europe" and do not appraise the historical significance of the "open Europe." As such, their denial of Europe naturally turns into a moral project that has to correct the relationship with the Other through a radical change of roles: since Europe has denied other identities, it itself now must be denied. P. Manent generalizes this moralist position that idealises "opening up to 
the Other" by proclaiming, "We mention Europe only in order to destruct it. We acknowledge only humanity! We do not have our own existence, and do not desire our own existence" (2006: 93).

The denial of substantiality of one's own existence determines the relativist perception strategy of the philosophical, cultural, and political Europe. Since its main feature is a critique of a historically formed identity to the extent of its moral denial, this strategy has acquired contours of an idealistic, even visionary programme of Europe's future. In a historiographical sense, the most characteristic examples of such a perception of Europe can found in the collective work Penser l'Europe à ses frontières. Géophilosophie de l'Europe (Guénon 1993), which contains contributions from famous postmodernist authors - G. Agamben, A. Badiou, J. Derrida, J.-L. Nancy, among others - as well as in the collection of works by a Switzerland-based research group La Riponne, Europes intempestives (2006). In sum, the position on the philosophical, the cultural, and the political Europe these works take is one where Husserl's "idea of infinity," the European telos of humanity interpreted through the concepts of colonial expansion and ethnocentricity, gives way to a specific ideology of universal humanism that neutralizes the question of differences among identities. According to this position, the concept of humanity, just like the doctrine of human rights, is understood independently of the search for a "metaphysical truth." The philosophical Europe is not a motherland of some specific thinking but an all-accepting land; the cultural Europe can only be a multicultural society, in which the historical evolution of cultural Europeanness has to end in a peaceful gathering of cultural abundance that is itself developing towards a global community experiencing pure humanity and rejecting the principle of substantialist identities. Similarly, any form of unity of the political Europe has to be rooted in radically new categories that neutralize the differences of identities. In this context, Agamben's suggestion to replace the concept of a "citizen" with a universal category of a "refugee," which in fact would substantiate anew the political project of Europe, is especially characteristic. The radical programme of deconstruction of the European identity which, one may say, reaches a zero point or positions for a new start, should not be surprising, remembering that, from this perspective, the European identity is regarded not as an ontological reality but merely as a product of a constructivist subjective mind.

The third strategy of perception of Europe is to be regarded as a strategy seeking peace in Europe and the entire world. Its essence is defined by the chosen method: Europe can become a source of world peace by creating in itself an empty identity space, where numerous other identities from the rest of the world would, in the long run, neutralize their own identities following the example of Europe that neutralised its own identity. This is why I call this strategy of the European perception "hollow." As one can see, this description does not have any pejorative connotation but corresponds to the configuration of the perception of Europe discussed above. It has been confirmed by one of the protagonists of this conception, Badiou, to whom "Europe empties or scoops out thinking" (1993). 


\section{Perceptions of Europe in Lithuania}

In Lithuania, one can come across all strategies of European perception that have been presented above. However, only the two classical understandings of Europe - the closed and the open - have been subjected to serious scientific analysis, and most prominently those found in the works of Schmitt and Brague, respectively. Notably, the perception of the closed Europe evokes two opposite strategic reactions, as different authors base their support for or rejection of Europe based specifically on its interpretation through to the prism of the closed identity. The support for the vision of the closed European identity is expressed in the radical analyses of A. Degutis and V. Radžvilas, both of whom are politically positioned in the far right. On the opposite end, A. Andrijauskas engages in a historical, cultural, and philosophical criticism of the role Europe plays in the world (namely, the European inclination to colonization) based on a generalization of the European civilisation through the concept of eurocentrism. A. Andrijauskas, however, does not take a postmodern deconstructionist position - as a representative of cultural comparative studies, he personally supports the paradigm of Oriental wisdom and devalues the purely rational tradition of European thinking. Meanwhile, the strongest substantiation of the idea of the open Europe in Lithuania comes from L. Donskis and B. Kuzmickas. Their writing focuses on the philosophical, the cultural, and the political Europe permeated with an openness of thinking, which is regarded as the "soul of Europe" (for Donskis) or the "essence of Europe" (for Kuzmickas) and which has, historically speaking, more or less successfully competed with the inclination to closedness. I also position my own research in this category of the proponents of openness. Lastly, there are numerous representatives of deconstructionist thought in Lithuania as well: poring over the Lithuanian intellectual literature, one will easily find original texts that analyze the ideas of G. Deleuze, Derrida, or Badiou. However, fragments notwithstanding, I could not find any fundamental analyses of the European idea based on the school of postmodern thinking. To date, Lithuania lacks its own version of the substantiation of the hollow Europe, in spite of the obvious potential for one to appear.

Regardless of which perception of Europe Lithuanian authors employ, they usually, if not always, confront it with the question of the national Lithuanian identity. As such, the relationship between the ideas of Europe and Lithuania forms the main prism through which the European concept is interpreted. The most fundamental analysis and classification of European perceptions through this lens come from N. Putinaitè, in her Trys lietuviškosios Europos [Three Lithuanian Europes] (2014). The author distinguishes three main European visions rooted in the Lithuanian mind: "The aggressive, rejecting and destroying the particularity of nation; the civilizational ideal that challenges nation to intensive cultural and political development; the politically and culturally specific "own" (Eastern) Europe created by neighbouring nations" (2014: 201). Though this classification of the perceptions of Europe is different from my scheme of closedness-opennesshollowness, the two schemes are mutually complementary. Configurations of the closed, the open, and the hollow thinking are easily recognizable in Putinaitè's 
variants of "Lithuanian Europes," though they are not referred to as such. The "aggressive Europe" undoubtedly arises out of the closed strategy of perception of Europe. Historically, this Europe is interpreted as the one that destroyed the original (pre-Christian) Lithuanian identity through a type of European colonization-Lithuania's conversion to Christianity that started in the 14th century. Most interestingly, nowadays some in the Lithuanian society associate the aggressive image of Europe with the European Union interpreted through the prism of the hollow identity: they allege that, by maintaining the ideal of multiculturalism, the EU seeks to impose the process of identity's neutralization (deconstruction) on its member nations in a dictatorial way. Both shapes of the aggressive Europe - the one that corresponds to the norms of the closed identity and the one corresponding to the norms of the open identity - evoke the same reaction of closing oneself in one's own identity to protect it. (In her book, Putinaitè also highlights the highly intriguing phenomenon of the transition from the closed identity to the hollow, and vice versa; unfortunately, it does not receive proper analysis). Meanwhile, Europe as a "civilizational ideal" and Europe as a cultural and a political union of regions corresponds to the strategy of perception of the open European identity. However, in the case of the civilizational European ideal, a certain tendency of depreciating one's Lithuanian identity can be discerned - a feature not of authentic openness that seeks maturity of one's identity; instead, an inclination to self-denial can be discerned and, thus, a certain variant of hollowness. Similarly, if in a reverse trajectory, a tendency of praising one's identity in regard to other identities is observed in the conception of the union of European regions, as the union primarily reflects geopolitical needs rather than the need for the Other as a source of my maturity. Therefore, motives of closedness are born here. Despite these divergences, openness remains the prevailing vector of thinking in both cases.

\section{Conclusion}

The need to analyze the relationship between the closed, the open and the hollow identities is shaping to be the main scientific challenge in the research of the Europe idea. Specifically, when analyzing the philosophical, the cultural and the political Europe, the connection that reminds one of a natural transition between closedness and hollowness needs observation. Based on the premises presented above, it seems that the closed consciousness in Europe is transforming into nihilism towards identity, ontological emptiness, and a state of hollowness. In this transformation, the ongoing breakdown of closedness functions according to the principle of a spring - the more contracted the original state, the stronger the rebound, to the extent that the leap out of captivity ends in a chaotic emancipation from any norms. However, the reverse can also be observed. Hollowness leads to closedness. Ethical relativism, the state of negation of one's own identity, and a sense of emptiness turn into an obsessive need to regulate by law every discussion occurring in the public sphere and to a dictate of new political correctness, something we notice in the expression of the so-called neoliberal politics. In other 
cases, the perceived emptiness of identity determines a purely psychological the need for a closed identity and for a revival of strict conservatism, as if the only way to escape the threat of losing identity that hollowness poses is to make the substantiality of identity absolute, to close within it, to protect the space of one's identity's from everything that surrounds it; this need may also account for the widespread and rising popularity of the far right in recent years. Interestingly, this natural circulation between closedness and hollowness is characteristic only of Europe. One possible explanation for this could be that the third form of identity - the open one -is much stronger in the European civilisation than anywhere else. Authentic openness is both the reason for the cyclicality of closedness-hollowness and an exit from it. The open identity is freedom and risks, a challenge and a solution. Though freedom is a necessary condition for the maturity of an individual's identity, it also creates the conditions for mistakes that may lead one back into slavery. And, nevertheless, only the very freedom, and nothing else, provides the conditions to live a truly human life and to feel the spring of one's own authentic identity.

Obviously, reflections in this thematic field require philosophical substantiation. I tried to do this in my monograph Europos mastymo kryptys ir ateitis [Directions and Future of European Thinking] (2015). Today, the Lithuanian society, just like all other societies that have become part of the philosophical, the cultural, and the political space of Europe, has also become a field of negotiations between all three conceptions of identity - the closed, the open, and the hollow. Accordingly, the relationship between the European and the Lithuanian, just like the relationship between Europe and all other nations, should be researched precisely from this dynamic perspective.

\section{Bibliography}

Aleksandravičius P., 2015, Europos mastymo kryptys ir ateitis, Vilnius.

Aleksandravičius P., 2016, "The Need for Dialogic Consciousness in Postmodern Politic Society," Philosophy Sociology 27, pp. 14-22.

Badiou A., 1993, "Notes sur l'Europe," [in:] Penser l'Europe à ses frontières. Géopolitique de l'Europe, D. Guénon (ed.), La Tour-d'Aigues, pp. 88-99.

Beck U., 2007, "Understanding the Real Europe: A Cosmopolitan Vision," [in:]

U. Beck, Diversity and Culture. Penser l'Europe, Paris, pp. 24-53.

Bergson H., 1932, Les deux sources de la morale et de la religion, Paris, pp. 123-148.

Brague R., 1992, Europe, la voie romaine, Paris.

Cheneval F., 2005, La Cité des peuples, Paris.

Crépon M., 2006, Altérités de l'Europe, Paris.

Derrida J., 1991, L'Autre Cap, Paris.

Dewitte J., 2010, "Comment parler de l'identité européenne?," [in:] L'identité de l'Europe, Ch. Delsol (ed.), Paris, pp. 123-148.

Ferry J-M., 1996, L'Ethique reconstructive, Paris.

Ferry J.-M., 2005, Europe, la voie kantienne, Paris.

Ferry J.-M., 2013, L'Idée d'Europe, Paris. 
Ferry J.-M., 2010, La République crépusculaire, Paris.

Gauchet M., 1985, Le Désenchantement du monde, Paris.

Guénon D., 1993, Penser l'Europe à ses frontières. Géopolitique de l'Europe, La Tour-d'Aigues.

Groupe de la Riponne, 2006, Europes intempestives, Paris.

Habermas J., 2006, Sur l'Europe, Paris.

Huntington S.P., 1996, The Clash of Civilizations and the Remaking of World Order, New York.

Husserl E., 1970, The Crisis of European Sciences and Transcendental Phenomenology, Evanston.

Maissen Th., 2016, "L'Affirmation de la Conscience Individuelle et l'Avènement des Etats-Nations," [in:] Histoire de la conscience européenne, A. Arjakovsky (ed.), Paris, pp. 157-177.

Manent P., 2006, La Raison des Nations, Paris.

Mattéi, J.-F. 2007, Le regard vide, Paris.

Mikkeli H., 1998, Europe as an Idea and an Identity, London.

Morin E., 1987, Penser l'Europe, Paris.

Patočka J., 2002, Plato and Europe, Stanford.

Popper K.R., 1945, The Open Society and its Enemies, London.

Putinaitė N., 2014, Trys lietuviškosios Europos, Vilnius.

Ricoeur P., 1992a, Oneself as Another, Chicago.

Ricoeur P., 1992b, "Quel éthos nouveau pour l'Europe," [in:] Imaginer l'Europe. Le marché européen comme tâche culturelle et économique, P. Koslowski (ed.), Paris, pp. 107-116.

Rorty R., 1989, Contingency, Irony, and Solidarity, Cambridge.

Schmitt C., 1996, The Concept of the Political, transl. G.D. Schwab, Chicago.

Schmitt C., 1970, Politische Theologie II, Berlin-Steglitz.

Sloterdijk P., 1994, Falls Europa erwacht. Gedanken zum Programm einer Weltmacht am Ende des Zeitalters seiner politischen Absence, Frankfurt am Main.

Sontag S., 1967, "What's Happening in America," Partisan Review 34, pp. 57-58.

Tassin E., 2013, "L'Europe cosmopolitique: l'Epreuve du non européen," [in:] L'idée $d^{\prime}$ Europe, J.-M. Ferry (ed.), Paris, pp. 251-268. 